\title{
JURISDICTION CLAUSES AND THE CANADIAN CONFLICT OF LAWS*
}

\author{
GERALD B. ROBERTSON**
}

\begin{abstract}
Jurisdiction clauses in contracts present significant problems to the parties to the contract and to the courts which must interpret them. The author discusses the difficulties which arise when a contract attempts to oust the jurisdiction of the court and the approaches taken by the court to overcome or comply with jurisdiction clauses. Both English and Canadian cases are reviewed in a survey of the prima facie, forum conveniens and ousting of jurisdiction approaches.
\end{abstract}

\section{INTRODUCTION}

It is common for interprovincial contracts, and more especially international contracts, to include a clause whereby the parties agree to refer any dispute arising from the contract ${ }^{1}$ to the exclusive jurisdiction of the courts of a particular country or province. This type of clause, often referred to as a "jurisdiction" or "forum selection" clause, raises two main issues with respect to jurisdiction. First, can a court exercise jurisdiction solely on the basis of a jurisdiction clause in the parties' contract? The second issue, much more common in practice, involves the situation in which one party commences proceedings in a country or province other than the one selected in the contract. What approach should the courts adopt to such proceedings brought in breach of a forum selection agreement?

\section{A. The Jurisdiction Clause as a Basis for Jurisdiction.}

This first issue is relatively straightforward. If the defendant is present within the province there will be no need for the plaintiff to rely on the clause to found jurisdiction since this will be done simply by personal service on the defendant. The clause becomes relevant, however, if the defendant is not present within the jurisdiction. In such a case, it is clear that the jurisdiction clause constitutes a ground on which the court may grant an order permitting service ex juris. Thus the Alberta Rules of Court provide that: ${ }^{2}$

Service outside of Alberta ... may be allowed by the Court whenever...

(f) the proceeding is to enforce, rescind, resolve, annul or otherwise affect a contract or to recover damages or obtain any other relief in respect of a contract ...

(iv) in which the parties thereto agree that the courts of Alberta shall have jurisdiction to entertain any action in respect of the contract.

In provinces in which no prior application by the plaintiff is required to serve ex juris, the existence of a jurisdiction clause in the contract entitles him to serve the defendant ex juris. ${ }^{3}$ It should be noted, however,

* I am grateful to my colleague Professor P.J.M. Lown for his helpful comments on an earlier draft of this article.

* Visiting Professor, Faculty of Law, University of Alberta; Lecturer in Law, University of Leicester, England.

1. Although most of the cases dealing with jurisdiction clauses involve actions framed in contract, such a clause has been held to apply to actions framed in tort - see The Makefjell [1976] 2 Lloyd's Rep. 29 (C.A.); The Sindh [1975] 1 Lloyd's Rep. 372 (C.A.); S.M. Knight, "A voidance of Foreign Jurisdiction Clauses in International Contracts" (1977) 26 I.C.L.Q. 664.

2. R. 30(f)(iv).

3. See for example Ontario Rules of Practice, R. 25(l)(f)(ii). 
that in all provinces a forum selection clause confers jurisdiction only if the court would have possessed jurisdiction had the defendant been served within the province. Thus, for example, a forum selection clause cannot confer jurisdiction in a divorce case in which the requirements of section 5 of the Divorce Act ${ }^{4}$ are not satisfied. Similarly, it is doubtful whether the parties' contract could confer jurisdiction in a case dealing exclusively with title to foreign land. ${ }^{5}$ In other words, a jurisdiction clause has no effect in a case in which the court is deprived of jurisdiction because of the nature of the subject matter involved.

In provinces such as Alberta which require the plaintiff to apply for leave before serving ex juris, it is well established that the court's power to grant such an order is discretionary. ${ }^{6}$ Even in provinces which allow the plaintiff to serve $e x j$ uris as of right if one of the grounds are established, the court has a discretion to set aside the service on application, ${ }^{7}$ although it is not clear whether this discretion is as extensive as in the case where leave is required. ${ }^{8}$ Nevertheless it is clear that in both cases some degree of discretion is involved or remedy sought.

Thus it can be seen that a forum selection clause does have the effect of conferring jurisdiction on the chosen court but that the court retains a discretion to decline to exercise that jurisdiction, based on an overriding consideration of forum conveniens. ${ }^{9}$ It should be noted, however, that there is no reported case, either in Canada or in England, in which a court has declined to exercise jurisdiction conferred by a clause in the parties' contract.

\section{B. Proceedings Brought in Breach of a Jurisdiction Clause.}

The issue with which this article is primarily concerned is the approach which Canadian courts in the common law provinces adopt in relation to proceedings instituted in breach of a jurisdiction clause. In England this issue is litigated frequently, particularly in the Admiralty Division, primarily because of the fact that jurisdiction clauses are almost standard form in international maritime contracts. ${ }^{10} \mathrm{By}$ comparison, there are few

4. R.S.C. 1970 , c. D-8, as am..

5. Hawks v. Hawks (1921) 59 D.L.R. 430 (S.C.C.), applying the rule in British South Africa Co. v. Companhia De Mocambique [1893] A.C. 602 (H.L.).

6. Mercantile Bank of Canada v. Hearsey Transport Ltd. (1976) 1 Alta. L.R. (2d) 238 (S.C.T.D.); Antares Shipping Corp. v. The Capricorn [1977] 2 S.C.R. 422.

7. See for example Ontario Rules of Practice, R. 29.

8. See P.J.M. Lown, "Conflict of Laws: Jurisdiction, Recognition and Enforcement", chapter 14 of C.R.B. Dunlop, Creditor - Debtor Law in Canada (1981) at 474; E. Edinger, "Discretion in the Assumption and Exercise of Jurisdiction in British Columbia" (1982) 16 U.B.C.L. Rev. 1.

9. See Antares Shipping Corp. v. The Capricorm supra n. 6; Talbot v. Pan Ocean Oil Corp. (1977) 3 Alta. L.R. (2d) 354 (S.C.T.D.).

10. See for example The Morviken [1982] 1 C.L. 225 (C.A.); The Blue Wave [1982] 1 Lloyd's Rep. 151; Trendtex Trading Corp. v. Credit Suisse [1981] 3 All E.R. 520 (H.L.); The El Amria [1981] 2 Lloyd's Rep.119 (C.A.); The El Amria and El Minia [1981]2 Lloyd's Rep. 539; The Star of Luxor [1981] 1 Lloyd's Rep. 139; The Panseptos [1981] 1 Lloyd's Rep. 152; The Lisboa [1980] 2 Lloyd's Rep. 546 (C.A.); The Kislovodsk [1980] I Lloyd's Rep. 183; Carvalho v. Hull Blyth (A ngola) Ltd. [1979] 1 W.L.R. 1228 (C.A.); The Vishva Prabha [1979] 2 Lloyd's Rep. 286; The Christos [1977]1 Lloyd's Rep. 109; The Adolf Warski [1976] 2 Lloyd's Rep. 241 (C.A.); The Makefjelh supra n. 1; The Sindh, supra n. 1; Evans Marshall \& Co. v. Bertola SA [1973] 1 W.L.R. 349 (C.A.); The Eleftheria [1970] P. 94; YTC Universal Ltd. v. Trans Europa [1973] 1 Lloyd's Rep. 480 (C.A.); The Chaparral [1968] 2 Lloyd's Rep. 158 (C.A.); Mackender v.Feldia A.G. [1967]2 Q.B. 590 (C.A.); The Fehmarn [1958] 1 W.L.R. 159 (C.A.). 
Canadian cases dealing with this issue, and these cases display inconsistency in their approach. It is proposed in this article to examine the Canadian decisions under three headings, which correspond to what the present writer considers to be the three distinct approaches adopted by the courts in Canada to the question of jurisdiction clauses. Particular emphasis is placed on the examination of the third approach, an approach which has been expressly rejected by all other common law countries.

\section{THE "PRIMA FACIE" APPROACH}

\section{A. The English Rule}

English law is well established with respect to proceedings brought in breach of a clause conferring exclusive jurisdiction on the courts of a foreign country. The rule set out in Dicey and Morris is as follows:"

Where a contract provides that all disputes between the parties are to be referred to the exclusive jurisdiction of a foreign tribunal, English courts will stay proceedings instituted in England in breach of such agreement, unless the plaintiff proves that it is just and proper to allow them to continue.

The most frequently cited judgment in this context is that of Brandon J.in the case of The Eleftheria.12

The principles established by the authorities can, I think, be summarised as follows: (1) Where plaintiffs sue in England in breach of an agreement to refer disputes to a foreign court, and the defendants apply for a stay, the English court, assuming the claim to be otherwise within its jurisdiction, is not bound to grant a stay but has a discretion whether to do so or not. (2) The discretion should be exercised by granting a stay unless strong cause for not doing so is shown. (3) The burden of proving such strong cause is on the plaintiffs. (4) In exercising its discretion the court should take into account all the circumstances of the particular case. (5) In particular, but without prejudice to (4), the following matters, where they arise, may be properly regarded: - (a) In what country the evidence on the issues of fact is situated, or more readily available, and the effect of that on the relative convenience and expense of trial as between the English and foreign courts. (b) Whether the law of the foreign court applies and, if so, whether it differs from English law in any material respects. (c) With what country either party is connected, and how closely. (d) Whether the defendants genuinely desire trial in the foreign country, or are only seeking procedural advantages. (e) Whether the plaintifis would be prejudiced by having to sue in the foreign court because they would: (i) be deprived of security for their claim; (ii) be unable to enforce any judgment obtained; (iii) be faced with a time-bar not applicable in England; or (iv) for political, racial, religious or other reasons be unlikely to get a fair trial.

It is apparent that Brandon J.'s reference to the plaintiff having to show "strong cause" why the action should not be stayed varies somewhat from the language used by Dicey and Morris. However it has recently been held by the English Court of Appeal that there is no real difference between the two tests. ${ }^{13}$ The effect of the rule is to place the onus on the plaintiff of showing sufficiently strong reasons why the action should not be stayed. This is in contrast to an application to stay proceedings where there is no jurisdiction clause, based on the principle of forum conveniens. In that case the onus lies with the defendant to satisfy the court that the proceedings should be stayed.14

The general rule is expressed in terms of "staying proceedings", but the issue can also arise in a different procedural context. If the plaintiff brings an action in personam in breach of a jurisdiction clause, and the defendant is not present within the jurisdiction, the defendant's recourse

11. Dicey and Morris on The Conflict of Laws (10th ed. 1980) at 255 (Rule 31).

12. [1970] P. 94 at 99-100.

13. Carvalho v. Hull Blyth IAngolal Ltd. [1979] 1 W.L.R. 1228 (C.A.).

14. MacShannon v. Rockware Glass Ltd. [1978] A.C. 795 (H.L.); The Atlantic Star [1974] A.C. 436 (H.L.); Mercantile Bank of Canada v. Hearsey Transport Ltd., supra n. 6. 
is not to apply for a stay of proceedings but rather to resist the plaintiff's application for leave to serve ex juris. ${ }^{15}$ In this situation the same rule applies - the onus is on the plaintiff to show strong reasons why leave to serve ex juris should be granted notwithstanding the jurisdiction clause.$^{16}$ Indeed, some English courts and academic writers have taken the view that there is a heavier onus on the plaintiff in this situation than in the situation where the defendant applies for a stay of proceedings. ${ }^{17}$ This distinction has been questioned by Canadian writers ${ }^{18}$ with, it is submitted, some justification. Both situations involve the exercise of discretion. In the former, the plaintiff is asking the court to exercise its discretion to grant leave to serve $e x$ juris and thereby assume jurisdiction which it would not otherwise have; in the latter, the plaintiff is asking the court not to exercise its discretion to stay proceedings. The onus on the plaintiff should not be regarded as varying according to whether or not the court already possesses jurisdiction. Rather the onus should be regarded as stemming from the fact that the plaintiff's action is in breach of the parties' agreement, and for that reason the onus should be the same regardless of whether the case involves the staying of proceedings or leave to serve ex juris.

\section{B. The Canadian Cases}

A number of Canadian cases follow the English approach set out above, namely, that prima facie the jurisdiction clause should be enforced and the onus of showing strong reasons for doing otherwise lies with the plaintiff. The clearest example of this approach in Canada is the recent case of G. \& E. Auto Brokers Ltd. v. Toyota Canada Inc. ${ }^{19}$ This involved a commercial contract which included a clause referring all disputes to the exclusive jurisdiction of the Ontario courts. The plaintiff commenced proceedings in British Columbia and the defendant, relying on the jurisdiction clause, applied to have the proceedings stayed. The court referred to the decision of Brandon J. in The Eleftheria, ${ }^{20}$ summarising that decision as follows: ${ }^{21}$

[T] $\mathrm{T}$ e Court is not bound to grant a stay but has a discretion whether to do so or not. The discretion should be exercised by granting a stay unless strong cause for not doing so is shown. The burden of providing such strong cause is on the plaintiff.

After considering the plaintiff's arguments, the Court concluded that these were not of sufficient strength to override the parties' agreement that the Ontario courts should have exclusive jurisdiction. The approach

15. In provinces in which no leave is required the defendant's recourse would be to apply either to have the service ex juris set aside or to have the proceedings stayed. See also Lam Company v. $O^{\prime}$ Lori Holdings $L t d$. (1981) 27 B.C.L.R. 378(C.A.), in which the issue of the jurisdiction clause arose in the context of the defendant's application to set aside summary judgment.

16. The Makefjelh supra n. 1; YTC UniversalLtd. v. Trans Europa [1973] 1 Lloyd's Rep. 480 (C.A.); Mackender v. Feldia A.G. [1967] 2 Q.B. 590 (C.A.).

17. Evans Marshall \& Co. v. Bertola SA [1973] 1 W.L.R. 349 at 362 (C.A.); The Makefjell. supra n. 1 at 34-35; Dicey and Morris, supra n. 11 at 255; 0 . Kahn-Freund, "Jurisdiction Agreements: Some Reflections" (1977) 26 I.C.L.Q. 825 at 852.

18. J. - G. Castel, Canadian Conflict of Laws (1975) at 311-312; Z. Cowen and D. Mendes Da Costa, "The Contractual Forum: A Comparative Study" (1965) 43 Can. Bar Rev. 453 at 457.

19. (1980) 117 D.L.R. (3d) 707 (B.C.S.C.).

20. Supra n. 12.

21. Supran. 19 at 709. 
adopted in $G$. \& E. Auto Brokers $L t d$. has been expressly followed in two subsequent British Columbia decisions. ${ }^{22}$

A slight variation on this prima facie approach, which appears to cast an even heavier burden on the plaintiff, is evident in two Ontario decisions. In Poly-Seal Corp. v. John Dale Ltd., Landerville J. enunciated the principle that prima facie the court should enforce the jurisdiction clause unless it is shown that "the foreign Court could not possibly give any relief to the parties". ${ }^{23}$ This principle, if applied, would certainly have the effect of making the plaintiff's task more difficult by seriously limiting the grounds on which the court could refuse to grant a stay. However, although the recent case of Gulf Canada $L t d$. v. Turbo Resources $L t d .^{24}$ purports to apply the principle in Poly-Seal the court referred to that principle as being that it ought to grant a stay "unless it is shown that the matter cannot be properly dealt with in the for eign Court". ${ }^{25}$ This is much wider than the principle actually enunciated in Poly-Seal and indeed seems to approximate the rule expressed by Dicey and Morris set out above.

The cases discussed above clearly represent the adoption of the English rule of prima facie enforcement of jurisdiction clauses. ${ }^{28}$ This is the "majority approach" in Canada, although with so few cases on point it is perhaps artificial to use this term. It is of interest to note that in all but one of the cases which adopt the prima facie approach the jurisdiction clause was enforced. ${ }^{27}$

\section{THE "FORUM CONVENIENS" APPROACH}

Three Canadian cases adopt what may be termed the "forum conveniens" approach to jurisdiction clauses. Under this approach the principle of prima facie enforcement is not emphasized; instead, the jurisdiction clause is regarded simply as one factor to be taken into account in considering the question of forum conveniens. At first sight, the difference between the two approaches may appear to be simply one of emphasis. This, however, is not the case; there is a significant difference in principle between the two approaches. Moreover, it is probably no coincidence that those courts which have adopted the prima facie approach have generally enforced the jurisdiction clause, whereas the Canadian courts which have adopted the forum conveniens approach have uniformly declined to enforce the clause. Thus the forum conveniens approach appears to have been used as a means of avoiding the enforcement of jurisdiction clauses.

\section{A. The English Background}

To understand the Canadian cases which have adopted the forum conveniens approach to jurisdicton clauses, one must begin with the decision

22. Lam Company v. O'Lori Holdings Ltd, supra n. 15; Pirrana Small Car Centres Ltd. v. Rumm, Measures and Kathcare Enterprises $L$ td. [1981] 5 W.W.R. 79 (B.C.S.C.).

23. [1958] O.W.N. 432 (H.C.).

24. (1980) 18 C.P.C. 146 (Ont. H.C.).

25. Id. at 148 .

26. See also Atlantic Sugar Refineries Co. v. R.T. Tamblyn \& Partners Ltd. (1974) 3 O.R. (2d) 195 (H.C.).

27. The sole exception is Pirrana Small Car Centres Ltd. v. Rumm, Measures and Kathcare Enterprises Ltd, supra n. 22, in which the court held that the plaintiff had discharged the onus of proving strong cause why the jurisdiction clause should not be enforced. 
in 1957 of the English Court of Appeal in The Fehmarn. ${ }^{28}$ Like so many English cases dealing with jurisdiction clauses, this involved an action by cargo owners against a shipowner in respect of damaged cargo. The proceedings were brought in England contrary to a clause in the bill of lading referring all disputes to the exclusive jurisdicton of the Russian courts. At first instance Willmer J. emphasised the prima facie approach; indeed, a dictum from his judgment forms the basis of the prima facie rule as expressed by Dicey and Morris. ${ }^{29}$ On the facts of the case, Willmer J. concluded that sufficiently strong reasons had been established to justify refusing to stay the proceedings.

The Court of Appeal affirmed this decision, but in doing so, little, if any, emphasis was placed on the prima facie approach. Although Morris L.J. made reference to this approach, ${ }^{30}$ Hodson L.J. merely stated that "there is no indisposition on the part of the courts of this country to give effect to such a bargain." 31 However, the importance of this decision lies in the judgment of Lord Denning who enunciated a principle which represented a significant departure from the prima facie approach. Lord Denning was of the opinion that the court should determine the issue by asking, "Is this dispute a matter which properly belongs to the courts of this country?", and by looking to see "with what country is the dispute most closely concerned". ${ }^{32}$ Lord Denning and Hodson L.J. both stressed the importance of convenience and clearly regarded the jurisdiction clause as merely one of several factors to be taken into account in determining the question of forum conveniens.

Lord Denning's dictum was approved in the later Court of Appeal decision in Evans Marshall \& Co. v. Bertola S.A., ${ }^{33}$ which involved the plaintiff applying for leave to serve ex juris notwithstanding a jurisdiction clause in favour of the Spanish courts. In upholding the lower court's decision to grant leave, the Court of Appeal paid no more than lip-service to the importance of enforcing jurisdiction clauses; indeed the court did not reiterate, let alone apply, the prima facie principle which had by that date replaced The Fehmarn as the governing principle. ${ }^{34}$ Instead, the court emphasized the importance of factors connected with convenience, particularly the fact that the substance of the case was exclusively connected with England.

The forum conveniens approach adopted in The Fehmarn, and Lord Denning's judgment in particular, have been criticized by several academic writers. ${ }^{35}$ Moreover, there are suggestions in a recent English Court of Appeal decision that for a trial judge to direct himself solely in

28. [1958] 1 W.L.R. 159 (C.A.).

29. [1957] 1 W.L.R. 815 at 819 ; see supra n. 11.

30. Supra n. 28 at 164.

31. Id. at 163 .

32. Id. at 162 .

33. Supra n. 17 per Edmond-Davies L.J. at 383.

34. See Mackender v. Feldia A.G., supra n. 16; The Chaparall [1968] 2 Lloyd's Rep. 158 (C.A.); YTC Universal Ltd. v. Trans Europa, supra n. 16; The Eleftheria, supra n. 12.

35. G.C. Cheshire and P.M. North, Private International Law (10th ed. 1979) at 114, n. 2; Kahn-Freund, supra n. 17 at 851; L. Collins, "Arbitration Clauses and Forum Selecting Clauses in the Conflict of Laws: Some Recent Developments in England" (1971) $2 J$. Maritime L. 363 at 375; A. Bissett-Johnson, "The Efficacy of Choice of Jurisdiction Clauses in International Contracts in English and Australian Law" (1970) 19 I.C.L.Q. 541 at 546; P. Webb, "The Fehmarn" (1958) 7 I.C.L.Q. 599. 
terms of Lord Denning's dictum in The Fehmarn would be an error of law. ${ }^{36}$ The Fehmarn is clearly not in accordance with the English law as it has subsequently developed. Indeed, it would appear that Lord Denning has abandoned the principle he enunciated there, since he has emphasized the principle of prima facie enforcement in a number of subsequent decisions. ${ }^{37}$

\section{B. The Canadian Cases}

The earliest Canadian case to adopt the forum conveniens approach is R.J. Polito v. Gestioni Esercizio Navi Sicilia Gens. ${ }^{38}$ This case involved an action for failure to deliver cargo in accordance with a bill of lading which included a clause giving exclusive jurisdiction to the Italian courts. The court declined to enforce the clause and refused the defendant's motion for a stay of proceedings. In doing so, the court quoted from Lord Denning's judgment in The Fehmarn and also cited dicta from earlier English decisions which emphasized the importance of convenience in determining the effect of jurisdiction clauses ${ }^{39}$ The court concluded that since a trial in the Italian courts would involve considerable inconvenience and would greatly increase the costs, the clause should not be enforced..$^{40}$

In considering $R$.J. Polito it must be borne in mind that it was decided only one year after The Fehmarn, and thus its reliance on that case is perhaps understandable. To a much lesser extent the same is true of $A . S$. May \& Co. Ltd. v. Robert Reford Co. $L t d$. decided in $1969,{ }^{41}$ although in the interim, two cases had been decided by the English Court of Appeal in which it emphasized the prima facie approach. ${ }^{42}$ Neither case was referred to in A.S. May \& Co.. Moreover, no reference was made to the case of Poly-Seal Corp. v.John Dale Limited, ${ }^{43}$ a decision of the same court ten years previously which, as was outlined above, emphasized the prima facie approach.

A.S. May \& Co. involved a bill of lading with an exclusive jurisdiction clause in favour of the Yugoslavian courts. In considering the defendant's application to stay proceedings the court cited passages from the judgments of Lord Denning and Hodson L.J. in The F' hmarn. ${ }^{44}$ Reference was also made to the decision in R.J. Polito. ${ }^{45}$ The court then gave brief consideration to factors relating to forum conveniens and concluded that "the place of convenience clearly lies in the jurisdiction of the Courts of Ontario." 48 The application for a stay was accordingly dismissed. The

36. The El Amria [1981] 2 Lloyd's Rep. 119 at 124 (C.A.).

37. Trendtex Trading Corp. v. Credit Suisse [1980] 3 All E.R. 721 at 740 (C.A.); YTC Univer. sal $L t d$ v. Trans Europa, supra n. 16 at 481 (C.A.).

38. [1960] Ex. C.R. 233.

39. Id. at $234,235$.

40. The court also concluded that its decision was in line with the earlier case of The Stromboli [1955] Ex. C.R. 1. This is extremely doubtful in view of the emphasis in that case on the importance of giving effect to the intention of the parties by enforcing the clause see id. at 2.

41. (1969) 6 D.L.R. (3d) 288 (Ont. H.C.).

42. Mackender v. Feldia A.G., supra n. 16; The Chaparalh supra n. 34. Although A.S. May \& Co. was decided after the decisions in YTC Universal L td. v. Trans Europa, supra n. 16, and The Eleftheria, supra $n$. 12, neither decision had yet been reported.

43. Supra n. 23.

44. Supra n. 41 at 291.

45. Id.

46. Id at 292. 
existence of the jurisdiction clause in the parties' contract appears to have had little, if any, effect on the outcome of the case.

As The Fehmarn is no longer the leading English decision on jurisdiction clauses, having been replaced by a large body of case law favouring the prima facie approach, one might suppose that Canadian courts would now place reliance on cases other than The Fehmarn. However, the recent British Columbia decision in Neptune Bulk Terminals Ltd. v. Intertec Internationale Technische Assistenz indicates otherwise. ${ }^{47}$ The reasoning of the court in this case is rather difficult to understand, and it is not entirely clear the extent to which it can properly be regarded as supporting the forum conveniens approach. The difficulty stems from the court's conclusion that the parties' contract did not contain a clear agreement to refer disputes to the German courts; thus counsel for the defendants was obliged to rest his application for a stay of proceedings on other grounds, namely form conveniens. However, notwithstanding this finding, the court proceeded to consider English cases which dealt with jurisdiction clauses. Once again, particular emphasis was placed on The Fehmarn and in fact no reference was made to any later English case. The court concluded that the forum conveniens was British Columbia, and accordingly the application to stay proceedings was dismissed.

In view of the court's finding that the parties had not agreed to confer jurisdiction on another court, it is difficult to understand why it was thought relevant to refer to cases involving jurisdiction clauses. Nevertheless, what is significant is that the court's examination of such cases was restricted to The Fehmarn.

\section{Criticism of the Approach}

In the The Eleftheria Brandon J. made the following observation: ${ }^{48}$

I think that it is essential that the court should give full weight to the prima facie desirability of holding the plaintiffs to their agreement. In this connection I think that the court must be careful not just to pay lip service to the principle involved, and then fail to give effect to it because of a mere balance of convenience.

This criticism goes to the root of the forum conveniens approach. Indeed, the three Canadian cases discussed under this heading do not even pay "lip service" to the prima facie approach. Rather, the whole issue is treated as one of determining the balance of convenience, with the jurisdiction clause being regarded as little more than a neutral factor in that determination.

It is submitted that the forum conveniens approach ought not to be followed in future Canadian cases. It patently places insufficient emphasis on the intention of the parties and on the cardinal principle of holding parties to their agreement. It completely overlooks the fact that the negotiation of the terms of the contract, and in particular the consideration therefor, may have been influenced by the inclusion of the jurisdiction clause. The form conveniens approach affords the plaintiff too great an opportunity of obtaining an advantage by repudiating one of the terms of the contract. Moreover, the advantage which the plaintiff seeks to obtain in this way may often be more than simply a procedural one. For example, proceedings in the foreign court may have become

47. (1981) 127 D.L.R. (3d) 736 (B.C.C.A.).

48. Supra n. 12 at 103. 
time-barred ${ }^{49}$ Similarly, there may be a considerable difference between the amount of damages which may be recovered in the two countries. ${ }^{50}$

For these reasons the forum conveniens approach ought to be rejected. This is not to suggest that jurisdiction clauses ought to be enforced in every case. There may well be circumstances in which, for a variety of reasons other than a mere "balance of convenience", it would not be just and proper to enforce the clause. However, adequate allowance is made for this in the prima facie approach.

It was submitted above that the forum conveniens approach has been used in Canada as a means of avoiding jurisdiction clauses, as is shown by the fact that all three of the cases discussed above decide in favour of not enforcing the clause. In this regard it is of interest to note that, whereas most of the Canadian cases which adopt the prima facie approach involve jurisdiction clauses in favour of another Canadian province, ${ }^{51}$ all three "forum conveniens" cases involve a clause in favour of a foreign country. ${ }^{52}$ This highlights another danger inherent in the forum conveniens approach, namely, the court applying too insular or parochial an approach to disputes between parties to an international contract.

\section{THE "OUSTING OF JURISDICTION" APPROACH}

Despite their divergence in approach, the cases discussed above are unanimous in their acceptance of one fundamental principle, namely, that the court has a discretion in deciding whether to enforce the jurisdiction clause. However, this principle is rejected in a number of Canadian cases which adopt an entirely different approach to jurisdiction clauses. In these cases the court is regarded as having no discretion once it is determined that the parties' contract gives exclusive jurisdiction to the courts of another country or province; the jurisdiction clause must be enforced. The court regards its jurisdiction as having been "ousted" by the parties' contract. This is by far the most interesting of the three approaches in that it is one which has been expressly rejected by all other major common law countries.

\section{A. The "Ousting" Principle}

In 1796 in the earliest English case involving a jurisdiction clause, Eyre C.J. commenced his judgment with the following principle: $:^{53}$

$[N]$ persons in this country can by an agreement between themselves exclude themselves from the jurisdiction of the king's courts ....

49. The question of how, if at all, enforcement of a jurisdiction clause should be affected by the fact that the plaintiff's action is time-barred in the foreign country is unsettled in English law - see The Blue Wave [1982] 1 Lloyd's Rep. 151; The Adolf Warski [1976]2 Lloyd's Rep. 241 (C.A.).

50. See for example The Morviken [1982] 1 C.L. 225 (C.A.) (difference in damages of approximately $\$ 25,000$ ); The Chaparall, supra $\mathrm{n} .34$ (difference in damages of approximately $\$ 1.3$ million).

51. See however Lam Company v. O'Lori Holdings Ltd, supra n. 15 (California); Poly-Seal Corp. v. John Dale Ltd, supra n. 23 (Sweden).

52. R.J. Polito v. Gestioni Esercizio Navi Sicilia Gens, supra n. 38 (Italy); A.S. May \& Co. v. Robert Reford Co., supra n. 41 (Yugoslavia); Neptune Bulk Terminals Ltd. v.Intertec Internationale Technische Assistenz, supra n. 47 (Germany).

53. Gienar v. Meyer (1796) 2 H. Bl. 603 at 606, 126 E.R. 728 at 730. 
This principle has been followed, inter alia, in England, ${ }^{54}$ the United States, ${ }^{55}$ Australia, ${ }^{56}$ and in the Canadian cases discussed above; indeed, one writer has observed that the principle has become "almost proverbial" ${ }^{57}$ For many years this principle led courts in the United States to regard jurisdiction clauses as void. However, since the U.S. Supreme Court decision in Zapata Off-Shore Co. v. The "Bremen" ${ }^{58}$ it has been accepted that the "ousting" principle does not have this effect. Rather, the principle invests the court with a discretion to decide whether to enforce the jurisdiction clause.

B. E.K. Motors Ltd. v. Volkswagen Canada Ltd.

The focal point of the "ousting" approach is the decision of the Saskatchewan Court of Appeal in E.K. Motors Ltd. v. Volkswagen Canada L td ${ }^{59}$ This case involved a contract between the Canadian importer and the Saskatchewan distributor of Volkswagen motor vehicles. A clause in the contract provided that the agreement was "subject to the laws of the Province of Ontario and to the exclusive jurisdiction of her Courts." The plaintiff brought an action in the courts of Saskatchewan, and the defendant applied for a stay of proceedings. This application was dismissed at first instance, MacPherson J. concluding that the balance of convenience was strongly in favour of the proceedings continuing in Saskatchewan. ${ }^{80}$ However, this decision was reversed by the Court of Appeal, Culliton C.J.S. outlining the basis for his decision as follows: ${ }^{\text {:1 }}$

The clause in the 1965 agreement does provide that the agreement is subject to the exclusive jurisdiction of the Ontario courts. That clause, so framed, in my opinion, does oust the jurisdiction of the Saskatchewan courts in respect of litigation arising out of that contract .... Thus, insofar as the 1965 agreement is concerned, any litigation arising therefrom cannot be entertained in the Saskatchewan courts and the doctrine of convenience has no application thereto.

The Court of Appeal clearly accepted that the parties could oust its jurisdiction by means of an exclusive jurisdiction clause, leaving it with no discretion in the matter. Under this approach, once the plaintiff establishes the existence of an exclusive jurisdiction clause in favour of another court, the court must decline to exercise jurisdiction.

The legal authorities on which the Court of Appeal based its decision

54. See for example The Fehmarn, supra n. 28, per Lord Denning at 162. It should be noted, however, that when the E.E.C. Convention on Jurisdiction and the Enforcement of Judgments in Civil and Commercial Matters (1968) is implemented in the United Kingdom, the effect of Article 17 thereof will be to remove the court's discretion in relation to jurisdiction clauses in cases to which the Convention applies - see Dicey and Morris, supra n. 11 at 228-229.

55. See for example Restatement (Second) of Conflict of Laws (1971) 80; Zapata Off-Shore Co. v. The "Bremen" (1972) 407 U.S. 1.

56. See for example Sheldon Pallet Manufacturing Co. v. New Zealand Forest Products Ltd. [1975] 1 N.S.W.L.R. 141; E.I. Sykes and M.C. Pryles, Australian Private International Law (1979) at 59; Bissett-Johnson, supra n. 35.

57. A Lenhoff, "The Parties' Choice of a Forum: 'Prorogation Agreements' " (1961) 15 Rutgers L. Rev. 414 at 431 . In Kulukundis Shipping Co. v. A mtorg Trading Corp. (1942) 126 F. 2d 978 at 984 the court referred to the "hypnotic power of the phrase oust the jurisdiction' ".

58. Supra n. 55. For an extensive examination of the American cases leading up to the Zapata decision, see K. Nadelmann, "Choice-of-Court Clauses in the United States: The Road to Zapata" (1973) 21 Am J.Comp.L. 124; see also J.T. Gilbert, "Choice of Forum Clauses in International and Interstate Contracts" (1976) 65 Kentucky L.J. 1.

59. [1973] 1 W.W.R. 466 (Sask. C.A.).

60. [1972] 2 W.W.R. 700 (Sask. Q.B.).

61. Supra n. 59 at 470. 
will be examined below. To date, E.K. Motors $L t d$. has been followed in only one case, namely, Harrington v. Industrial Sales $L t d .{ }^{,{ }^{6}}$ a decision of the Saskatchewan Queen's Bench. ${ }^{83}$ Moreover, it has been expressly rejected in two subsequent British Columbia cases. ${ }^{64}$ It should be noted, however, that despite the fact that E.K. Motors $L t d$. adopts an entirely different approach to jurisdiction clauses, its importance has gone largely unnoticed in subsequent cases and academic writing..$^{65}$ Thus, for example, in three recent Canadian cases involving jurisdiction clauses, two of which were decided at appellate level, no reference at all was made to the E.K. Motors Ltd. decision. ${ }^{66}$ Even more significant is the misrepresentation of E.K. Motors Ltd. contained in A tlantic Sugar Refiners Co. v.R.T. Tamblyn \& Partners, ${ }^{67}$ a case which appears to have adopted a prima facie approach to jurisdiction clauses ${ }^{68}$ The court referred ${ }^{69}$ to that part of the judgment of Culliton C.J.S. in E.K. Motors $L t{ }^{70}{ }^{70}$ in which he quotes the prima facie rule as enunciated in The Eleftheria. ${ }^{71}$ However, the court made no mention of the fact that Culliton C.J.S. went on to reject that approach in deciding that the court had no discretion in the matter.

Similarly, many academic writers have ignored, or at least have underrated, the importance of the E.K. Motors Ltd. decision. Thus, for example, although Professor Castel devotes twenty-three pages of his textbook on the Canadian conflict of laws to a discussion of forum selection clauses, ${ }^{72}$ his treatment of $E . K$. Motors $L t d$. is confined to two sentences. ${ }^{73}$ C. The Legal Basis of E.K. Motors Ltd.

In arriving at the conclusion that an exclusive jurisdiction clause ousts the court's jurisdiction, leaving it with no discretion in the matter, the Saskatchewan Court of Appeal in E.K. Motors Ltd. relied on only one authority, namely the decision of the Newfoundland Supreme Court in

62. [1973] 2 W.W.R. 330 (Sask. Q.B.).

63. It is suggested by Lown, supra n. 8 at 487 , that E.K. Motors $L$ td. was applied in Jannock Corp. v. R.T. Tamblyn \& Partners Ltd. (1975) 58 D.L.R. (3d) 678 (Ont. C.A.). This is arguable in view of the fact that $E$.K. Motors $L t d$ was not referred to in the course of the judgments and in view of the observation of Brooke J.A. (id. at 686) that: "The learned trial Judge quite properly held that the clause in the contract did not confer exclusive jurisdiction. In my respectful view, the clause adds little, if anything, to be considered."

64. G\&E A uto Brokers $L t d$ v. Toyota Canada Inc., supra n. 19; Pirrana Small Car Centres Ltd. v. Rumm, Measures and Kathcare Enterprises Ltd, supra n. 22.

65. See however Lown, supra n. 8 at 487 , in which E.K. Motors Ltd. is emphasized as deviating from the accepted prima facie approach.

66. Gulf Canada Ltd. v. Turbo Resources Ltd, supra n. 24; Lam Company v. O'Lori Holdings Ltd. supra n. 15; Neptune Bulk Terminals Ltd. v. Intertec Internationale Technische Assistenz, supra n. 47.

67. Supra n. 26.

68. Although on balance this case appears to adopt a prima facie approach, the judgment of Van Camp J. arguably contains elements of all three approaches discussed in this article.

69. Supra n. 26 at 203-204.

70. Supra n. 59 at 468.

71. Supra n. 12 at $99-100$.

72. Supra n. 18 at $310-332$.

73. Id at 329. A possible explanation for this brevity of discussion is the extensive reliance, which the author acknowledges (id. at 310), placed on the article by Cowen and Mendes Da Costa, supra n. 18, which was published eight years before the decision in E.K. Motors Ltd. See also J. Swan, "Annual Survey of Canadian Law - Conflict of Laws: Part I" (1981) 13 Ottawa L.Rev. 123 at 127 ("The position that the courts have accepted in cases like E.K. Motors $L t d$. has not been regarded as the general rule for very long"). This appears either to overestimate the effect of the decision or to confuse it with the prima facie approach. 
Westcott v. Alsco Products of Canada Ltd. ${ }^{74}$ At first sight this reliance on Westcott appears to have been well founded. Although the jurisdiction clause in Westcott was held not to be exclusive in nature, conferring only concurrent jurisdiction on the Ontario courts, it is clear that the Supreme Court was of the opinion that, had the clause been exclusive, its effect would have been to oust the court's jurisdiction leaving it with no alternative but to enforce the clause ${ }^{75}$ However, if one goes one step further and examines the authorities relied upon by the court in Westcott, the soundness of the "ousting" approach begins to break down.

The Court in Westcott referred to three previous decisions, the first of which was Spurrell v. Furness Withy $\&$ Co.. ${ }^{78}$ Discussion of this case was restricted to an observation that it involved an exclusive jurisdiction clause in favour of the English courts. ${ }^{77}$ It is significant that the court in Westcott did not refer to the following dictum in Spurrell. ${ }^{78}$

The jurisdiction of Courts being part of the power inherent in the State by virtue of its sovereignty, is susceptible of no limitation not imposed by the State itself .... The practice of the Courts, however, is not now to regard agreements to submit disputes to arbitration as ousting the Court's jurisdiction, and this practice extends to permitting a reference of a dispute to the determination of a foreign tribunal.

This quotation is immediately followed by a reference to the case of Law v. Garrett, ${ }^{79}$ in which the English Court of Appeal clearly accepted that enforcement of a jurisdiction clause was ultimately a matter for the court's discretion. ${ }^{80}$

The second case relied upon in Westcott was the English decision in Buenos A yres And Ensenada Port Railway Co. v. Northern Railway Co. of Buenos Ayres. ${ }^{81}$ The court in Westcott cited this decision as authority for "the necessity for express and specific exclusion of other jurisdictions than the one chosen". ${ }^{82}$ In other words, this decision was relied upon as supporting the court's opinion that the parties could oust its jurisdicton by expressly declaring the forum selection clause to be exclusive in nature. However, this is a complete distortion of the decision in Buenos Ayres. Not only is there no mention in that case of "the necessity for express and specific exclusion of other jurisdictions", ${ }^{83}$ the case does not even involve a jurisdiction clause. Rather, the issue of "exclusive jurisdiction" arose out of the defendants' submission that exclusive jurisdiction over the plaintiffs' claim rested in the courts of the Argentine Republic by virtue of an Argentine statute.

Thus it can be seen that the first two cases relied upon by Westcott do not support the proposition that the effect of an exclusive jurisdiction clause is to oust the court's jurisdiction and consequently its discretion.

74. (1960) 26 D.L.R. (2d) 281,45 M.P.R. 394 (Nfld. S.C.).

75. Id. at 284 .

76. (1923) 11 Nfld. L.R. 287 (Q.B.).

77. Supra n. 74 at 285.

78. Supra n. 76 at 289.

79. (1878) 8 Ch. D. 26 (C.A.).

80. "II] ... parties choose to determine for themselves that they will have a forum of their own selection instead of resorting to the ordinary Courts, a prima facie duty is cast upon the Courts to act upon such an arrangement." - id. at 37.

81. (1877) 2 Q.B.D. 210.

82. Supra n. 74 at 285.

83. The only dictum which refers to the necessity of being "specific" relates to the need for the defendants' pleadings to be specific - see supra n. 81 at 212 . 
Indeed, the case of Spurrell v. Furness Withy \& Co. ${ }^{84}$ supports the opposite point of view.

The third authority relied upon in Westcott, namely, the English case of Hoerler v. Hanover, ${ }^{85}$ is equivocal in its support for the "ousting" proposition. This case involved a jurisdiction clause in favour of the German courts. It was held that the wording of the clause did not confer exclusive jurisdiction on the foreign court. The crucial part of the decision is the following extract of the report of Baron Pollock's judgment: ${ }^{86}$

If it had been intended to give the Court in Hanover exclusive jurisdiction it might have been so provided in express terms, but it had not been so provided, and it appeared enough to hold that it was intended simply to provide that the parties should not be precluded from the Court in Hanover. [Emphasis added]

The important question to be asked of this dictum is whether it implies that, had the clause been exclusive, it would have successfully ousted the court's jurisdiction, resulting in a stay of proceedings. Although it is not entirely clear, it appears that Westcott regarded Baron Pollock's dictum as making this implication. A similar conclusion was reached in Stairs v. Allan, Henry J. commenting on Hoerler as follows: ${ }^{87}$

It clearly appears, in the opinion of all the judges who heard [Hoerler v.Hanover], that, if the clause in question had been expressed so as to exclude the jurisdiction of the English courts, effect would have been given to it accordingly.

It is submitted that there is a more reasonable interpretation of Baron Pollock's dictum. The words "it appeared enough to hold" suggest that the court was simply deciding the case on the narrow ground that the clause was not exclusive, leaving open the wider question of the effect of an exclusive jurisdiction clause. However, even if it is correct to interpret Baron Pollock's dictum as supporting the "ousting" principle, this in itself must be of questionable authority in view of the earlier Court of Appeal decision in Law v. Garrett. ${ }^{88}$ This case clearly adopted the prima facie approach, thereby implying a residual discretion on the part of the court. Moreover, to the extent that Westcott relies on English decisions to support the "ousting" approach, it can no longer be regarded as good law in view of the fact that it is now firmly established in English law that enforcement of jurisdiction clauses is ultimately a matter for the court's discretion.

It is therefore submitted that, for the reasons outlined above, Westcott is of doubtful authority; consequently this casts a significant question mark over the authority of E.K. Motors Ltd.. Moreover, it is important to note that neither E.K. Motors $L t d$. nor Westcott made reference to two other Canadian decisions, both of which rejected the proposition that an exclusive jurisdiction clause ousts the court's jurisdiction and discretion. ${ }^{89}$

D. Other Authorities Relevant to the "Ousting" Approach.

Although not cited in either E.K. Motors Ltd. or Westcott, three other Canadian cases lend some support to the "ousting" approach. In both

84. Supra n. 76.

85. (1893) 10 T.L.R. 22.

86. Id. at 23.

87. (1896) 28 N.S.R. 410 at $414-415$ (C.A.).

88. Supra n. 79.

89. Carveth v. Railway Asbestos Packing Co. (1913) 9 D.L.R. 631 (Ont. S.C.); Brand v. National Life Assurance Co. (1918) 44 D.L.R. 412 (Man. K.B.). 
Hart \& Son, Ltd. v. Furness Withy \& Co. Ltd. ${ }^{90}$ and Kennedy v. Fiat of Turin (Italy $)^{91}$ it was held that an exclusive jurisdiction clause in favour of a foreign court ousts the Canadian court's jurisdiction and therefore must be enforced. However, it should be noted that in neither case were any authorities cited.

The third relevant case is Stairs v. Allan ${ }^{92}$ which is similar in many respects to the case of Westcott. Thus, although the court interpreted the jurisdicton clause as being non-exclusive in nature, it appears to have been of the opinion that an exclusive clause would have ousted the court's jurisdiction. As was the case in Westcott, great reliance was placed on Baron Pollock's dictum in Hoerler v. Hanover ${ }^{93}$ However, the most significant parallel between Stairs v. Allan and Westcott is the misplaced reliance on English decisions in support of the "ousting" approach. Thus in Stairs v. Allan the court relied, inter alia, on Gienar v. Meyer, ${ }^{94}$ overlooking the clear statement in that case to the effect that parties cannot oust the jurisdiction of the courts. ${ }^{95}$

However, Stairs v. Allan is significant in that, of all the cases to have adopted the "ousting" approach, this is the only one to have advanced reasoned criticism of the principle that parties cannot oust the court's jurisdiction. Thus, for example, Henry J. in Stairs v. Allan was of the opinion that this principle originated from English cases dealing with arbitration clauses and that it should not be extended to foreign jurisdiction clauses. ${ }^{96}$ Similar criticism can be found in the work of Professor Ehrenzweig. ${ }^{97}$ In a detailed criticism of the "ousting" principle, Ehrenzweig concludes as follows: $:^{98}$

Neither history nor rationale thus bear out the much-repeated general axiom that parties may not 'oust' the courts from their jurisdiction.

It may appear at first sight that, since the criticism advanced by Henry J. in Stairs v. Allan and by Professor Ehrenzweig cast doubt over the principle that parties cannot oust the court's jurisdiction, this lends support to the approach adopted in E.K. Motors Ltd. However, it is submitted that closer examination shows that this is not the case. In this regard it is crucial to appreciate that the "ousting" principle has been applied in support of two different conclusions. The first is that, since parties cannot oust the court's jurisdiction, any clause which purports to do so is void as being contrary to public policy. The alternative conclusion is that, since parties cannot oust the court's jurisdiction, an exclusive jurisdiction clause does not deprive the court of its overriding discretion in the matter. It is clear that Ehrenzweig was directing his criticism at the first meaning of the "ousting" principle. He was writing at a time when the majority of American courts took the view that exclusive jurisdiction clauses were void as being contrary to that principle. Ehrenzweig's criticism should therefore be regarded as referring only to the public

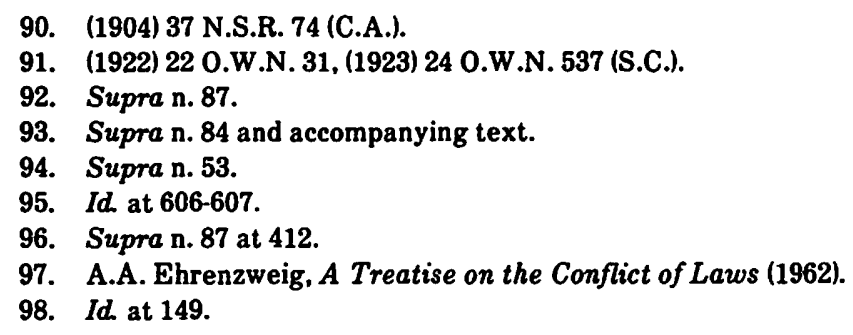


policy aspect of that principle, and it lends no support to the approach adopted in E.K. Motors $L t d$. This is confirmed by the fact that Ehrenzweig was of the opinion that A merican courts should revise their views on jurisdiction clauses and adopt a prima facie approach, ${ }^{99}$ a view which was finally endorsed by the U.S. Supreme Court in $1972 .{ }^{100}$

It is possible to place a similar interpretation upon the criticism advanced by Henry J. in Stairs v. Allan. ${ }^{10}$ It is important to note that the plaintiffs in Stairs v. Allan argued that the jurisdiction clause was contrary to public policy in that it purported to oust the court's jurisdiction. It was in dealing with this public policy argument that Henry J. advanced his criticism of the "ousting" principle and thus it is submitted that his criticism should be regarded in the same way as that of Ehrenzweig. Their criticism supports only the view that jurisdiction clauses are not void on public policy grounds. It does not support the E.K. Motors $L t d$. principle that the court has no discretion in the matter. As one leading work points out: ${ }^{102}$

It is, however, one thing to say that parties cannot take away from a court jurisdiction conferred upon it by law, and quite another to say that a court has no power to decline to exercise the jurisdiction which it undoubtedly possesses.

E. Criticism of the "Ousting" Approach.

The above discussion is intended to show that the authorities on which E.K. Motors $L t d$. rests are unsound in that they do not support the proposition that a court has no discretion when dealing with an exclusive jurisdiction clause. Moreover, it is submitted that there are strong policy reasons why a court should not regard itself as being obliged in every case to enforce such a clause. It is important that the court should retain a discretion, albeit one which is rarely exercised, to refuse to give effect to a jurisdiction clause in order to avoid serious injustice to the plaintiff. In particular, such a situation may arise where the jurisdiction clause is contained in a contract with respect to which there is significant inequality of bargaining power between the parties. For example, jurisdiction clauses are a common feature of many standard form contracts. As one writer has observed: ${ }^{103}$

What equality of bargaining power is there for the small shipper, the individual traveler, or the individual insured who finds a restrictive forum clause in his bill of lading, passenger ticket, or contract? What mutuality of benefit is there for these individuals in such a restriction?

This concern is reflected in the approach adopted by the American courts with regard to jurisdiction clauses, namely, that such clauses should be enforced unless to do so would be unreasonable and unjust. ${ }^{104}$ In deciding the issue of "reasonableness", particular emphasis is placed on the question of whether the clause is the product of free negotiation between parties of equal bargaining power. ${ }^{105}$ It is submitted that the prevalence of jurisdiction clauses in standard form contracts is in itself

99. See id. at 152-153.

100. Zapata Off-Shore Co. v. The "Bremen", supra n. 54.

101. Supra n. 87 at $\mathbf{4 1 2 - 4 1 3 .}$

102. Cowen and Mendes Da Costa, supra n. 18 at 469.

103. G. Bergman, "Contractual Restrictions on the Forum"(1960) 48 Calif. L. Rev. 438 at 447.

104. See Zapata Off-Shore Co. v. The "Bremen", supra n. 55 at 15.

105. "There are compelling reasons why a freely negotiated private international agreement, unaffected by fraud, undue influence or overweening bargaining power, such as that involved here, should be given full effect." - id. at 12-13. 
sufficient reason for rejecting the principle enunciated in E.K. Motors $L t d$. It is essential that the court retain a residual discretion to refuse to enforce a jurisdiction clause so as to avoid serious injustice to the plaintiff.

\section{ARBITRATION CLAUSES}

Further support for the prima facie approach to jurisdiction clauses can be found by analogy with cases involving arbitration clauses. For many years English courts regarded jurisdiction clauses as constituting a submission to arbitration, ${ }^{106}$ and there is support for this approach in some earlier Canadian cases. ${ }^{107}$ However, this has now been firmly rejected by English courts ${ }^{108}$ and no modern Canadian case adopts this approach. Nevertheless it is important to note that the prima facie approach in relation to the enforcement of arbitration clauses is entrenched by statute in all Canadian common law provinces. ${ }^{109}$ The leading case on the interpretation of these statutes enunciates the following principle: ${ }^{10}$

The authorities are to the effect that, when once it appears that the agreement for arbitration covers the claim stated in the action, it is the prima facie duty of the Court to allow the forum, which the parties have agreed to, to settle the matter in dispute, and the onus of showing that the case is not a fit one for arbitration is upon the person who opposes the stay of proceedings .... "'!

It is submitted that this lends support to the adoption of the prima facie approach in relation to jurisdiction clauses. Even although it is accepted that such a clause should not technically be regarded as a submission to arbitration, there appears to be no reason why the court should not adopt the same prima facie approach to jurisdiction clauses as it does to arbitration clauses.

It should be noted, however, that although the wording of the relevant sections of the Alberta Arbitration Act is the same as in other provinces, ${ }^{112}$ the case of Karlsen Shipping Co. v.Sefel J. \& Associates Ltd. appears to suggest that the onus lies with the person applying for a stay of proceedings. ${ }^{113}$ However, no reference was made in that case to the well established principle that the onus is on the person resisting the reference to arbitration to show sufficient reason why a stay of proceedings should not be granted. Thus, to the extent that Karlsen Ship-

106. See for example Law v. Garreth, supra n. 79; A ustrian Lloyd Steamship Co. v. Gresham Life Assurance Society Ltd. [1903] 1 K.B. 249 (C.A.); Logan v. Bank of Scotland (No. 2) [1906] 1 K.B.141 (C.A.); Kirchner \& Co. v. Gruban [1909] 1 Ch. 413; The Cap Blanco [1913] P. 130 (C.A.); The A thenee (1922) 11 Lloyd's Rep. 6 (C.A.); The Vestris (1932) 43 Lloyd's Rep. 86.

107. See for example Spurrell v. Furness Withy \& Co., supra n. 76; Brand v. National Life Assurance Co., supra n. 89; Kennedy v. Fiat of Turin (Italy), supra n. 91.

108. See in particular Racecourse Betting Control Board v. Secretary of State for Air [1944] 1 All E.R. 60 (C.A.).

109. Arbitration Act, R.S.A. 1980, c. A-43, ss. 3, 4; Arbitration Act, R.S.B.C. 1979, c. 18, s. 6; The Arbitration Act, R.S.M. 1970, c. A-120, s. 8; The Judicature Act, R.S. Nfld. 1970, c. 187, s. 179; Arbitration Act, R.S.N.B. 1973, c. A-10, s. 7; Arbitration Act, R.S.N.S.1967, c. 12, s. 5; Arbitrations Act, R.S.0.1980, c. 25, s. 7; Arbitration Act, R.S.P.E.I. 1974, c. A-14, s. 6; The Arbitration Act, R.S.S. 1978, c. A-24, s. 5.

110. Altwasser v. Home Insurance Company of New York [1933] 2 W.W.R. 46 at 50 (Sask. C.A.).

111. It is of interest to note that the Saskatchewan Court of Appeal in E.K. Motors Ltd. v. Volkswagen Canada Ltd, supra n. 59, made no reference to its own decision in Altwasser.

112. Supra n. 109.

113. [1977] 3 W.W.R. 122 at 125 (Alta. S.C.T.D.) 
ping Co. suggests the opposite principle, it should be regarded as doubtful.

\section{CHOICE OF LAW}

The above discussion has proceeded on the assumption the court should apply its own law, i.e., the lex fori, in determining the effect of a jurisdiction clause. However, if the proper law of the contract is not the lex fori, there may be some doubt as to whether the effect of the jurisdiction clause should be determined by the proper law or by the lex fori. Professor Castel has stated that: ${ }^{114}$

If a forum agreement is governed by a foreign law its effects should be determined by reference thereto.

This, however, appears to be incorrect. It is well established that the lex fori determines the effect of a jurisdiction clause. All the Canadian cases apply this principle, and it is supported by leading academic writers. ${ }^{115}$ However, the accepted view in England is that the lex fori does not govern the interpretation of a jurisdiction clause. ${ }^{116}$ In particular, the question of whether the jurisdiction clause is exclusive in nature is a matter for the proper law of the contract and not the lex fori. This principle was applied in the Canadian case of Carveth v.Railway A sbestos Packing Co., ${ }^{117}$ in which the Ontario court applied Quebec law as the proper law of the contract in determining whether the jurisdiction clause was exclusive in nature. On the other hand, there is at least one Canadian case in which this issue has been determined by applying the lex fori and not the proper law of the contract. ${ }^{118}$ It is submitted that this latter view is incorrect. It is well established that the interpretation of a contract is governed by its proper law. In this regard a jurisdiction clause should be treated no differently from any other clause in the contract. Consequently, the issue of whether a jurisdiction clause is exclusive in nature should be determined by the proper law of the contract and not by the lex fori.

\section{CONCLUSION}

There is no reported case in which the Alberta courts have had to determine the effect of an exclusive jurisdiction clause in favour of the courts of another country or province. When the opportunity to do so does arise, the court will have to decide which of the three approaches outlined above is to be preferred.

The forum conveniens approach, as reflected in cases such as The Fehmarn ${ }^{119}$ and A. S. May \& Co. v. Robert Reford Co., ${ }^{120}$ places insufficient emphasis on the need to hold parties to their agreement. Moreover, it has been used as a means of avoiding the enforcement of foreign jurisdiction clauses, and as such it has the disadvantage of reflecting too

114. Supra n. 18 at 314.

115. See for example Dicey and Morris, supra n. 11 at 256; Kahn-Freund, supra n. 17 at 827 et seq.- M. Pryles, "Comparative Aspects of Prorogation and Arbitration Agreements" (1976) 25 I.C.L.Q. 543 at 550-552.

116. Id. See also Evans Marshall \& Co. v. Bertola SA, supra n. 17; The Sindh, supra n. 1.

117. Supra n. 89.

118. Neptune Bulk Terminals Ltd. v. Intertec Internationale Technische Assistenz, supra n. 47.

119. Supra n. 28.

120. Supra n. 41. 
insular an approach to international disputes. As was observed by Chief Justice Burger in the U.S. Supreme Court: ${ }^{21}$

The expansion of American business and industry will hardly be encouraged if, notwithstanding solemn contracts, we insist on a parochial concept that all disputes must be resolved under our law and in our Courts ... We cannot have trade and commerce in world markets and international waters exclusively on our terms governed by our laws and resolved in our Courts.

The "ousting" approach adopted in E.K. Motors Ltd. v. Volkswagen Canada $L t d .{ }^{122}$ i.e., that the court has no discretion to refuse to enforce an exclusive jurisdiction clause, is unsound in principle. In particular, the only case relied upon in E.K. Motors $L t d$., namely, Westcott v. Alsco Products of Canada Ltd., ${ }^{123}$ does not support the proposition that a foreign selection clause ousts the court's jurisdiction. Moreover, there are strong policy reasons why the court should retain a residual discretion in relation to the enforcement of jurisdiction clauses, particularly in situations of serious inequality of bargaining power.

It is submitted that the prima facie approach to jurisdiction clauses ought to be adopted in future Canadian cases. This approach has the considerable advantage of giving due recognition to the intention of the parties to the contract, while at the same time affording the court a residual discretion to refuse to give effect to the jurisdiction clause in exceptional circumstances. It also emphasizes that the onus of proving such exceptional circumstances rests with the plaintiff. Finally, the adoption of the prima facie approach would add uniformity to the law in this area, since it corresponds to the approach adopted in relation to choice of law clauses in international and interprovincial contracts. ${ }^{123}$ For these reasons it is submitted that G. \& E. Auto Brokers $L t d$. v. Toyota Canada Inc. ${ }^{124}$ should be regarded as the leading Canadian case on this issue and the principles expressed therein followed in the future.

121. Zapata Off-Shore Co. v. The "Bremen", supra n. 55 at 9.

122. Supra n. 59.

123. Supra n.74.

124. See Vita Food Products, Inc. v. Unus Shipping Co. [1939] A.C. 277 (P.C.).

125. Supra n. 19. 